\title{
A systematic review of parents' experiences of raising a child with type 1 diabetes
}

\author{
SAFFRON SIMPSON, PAUL HANNA, CHRISTINA J JONES
}

\begin{abstract}
Background: There are currently 1.1 million young people estimated to have type 1 diabetes (T1D) across the world. A diagnosis of T1D impacts not only the children's lives but also those of the parents.

Aim: To understand the experiences of parents raising a child with T1D.

Methods: For inclusion, studies had to report qualitative data on parents' experiences of raising a child with a diagnosis of T1D. Parents included mothers, fathers or any other primary caregivers. Eleven databases were systematically searched for relevant articles. Studies were quality assessed and study characteristics extracted. The data were thematically synthesised.

Results: Thirty-two studies met the inclusion criteria. Thematic synthesis yielded two analytical themes: 'adjusting to a new reality' and 'navigating appropriate T1D support'. The five descriptive themes that contributed to these were 'distressing diagnostic experience', 'change of life routine', 'enablers and barriers to support from others', 'reconstruction of family dynamics' and 'psychological impact over time'.

Conclusions: Difficulties parents encounter in support received from school and healthcare professionals are highlighted. Parents' mental health needs should be attended to throughout T1D clinic appointments. Future research should explore fathers' experiences, as well as characteristics (such as employment status, education, relationship status and underlying mental health issues) which may affect parental experience, given the paucity of existing evidence.
\end{abstract}

Br J Diabetes 2021;21:43-58

Key words: type 1 diabetes, parents, children, systematic review, diabetes mellitus, qualitative research, experiences, carers

\section{Introduction}

A diagnosis of type 1 diabetes (T1D) impacts not only the life of the child but also the parents. There has been a wealth of research conducted into the experiences of parents raising a child with T1D.

School of Psychology, University of Surrey, Guildford, UK

Address for correspondence: Miss Saffron Simpson Room 12b AC 04, School of Psychology, University of Surrey, Guildford, GU2 7XH, UK

E-mail: saffron.simpson@surrey.ac.uk

https://doi.org/10.15277/bjd.2021.291
The existing literature reports an impact on, but not limited to, psychological well-being, ${ }^{1}$ finances, ${ }^{2}$ diet $^{3}{ }^{3}$ family life ${ }^{4}$ and social life. ${ }^{5}$ Whilst a mixed methods systematic review on psychological experiences of parents of children with T1D provided important information on the prevalence of psychological distress, ${ }^{6}$ the authors excluded studies that did not include parental psychological outcomes and studies that focused solely on family adjustment or functioning. Consequently, there may be important research pertaining to parents' experiences that were excluded. The aim of this current systematic review is to update and extend on the previous review by collating and synthesising the qualitative evidence on the broader range of parental experiences of raising a child with T1D. Therefore, this review offers a contribution to clinical practice by informing healthcare professionals about parental experience to enhance delivery of care to families and support T1D management.

\section{Methods}

This systematic review follows the Preferred Reporting Items for Systematic Reviews and Meta-analyses guidelines ${ }^{7}$ (Appendix 1 available at www.bjd-abcd.com) and was prospectively registered on Prospero (CRD42020173872). Studies were eligible for inclusion if they were (1) qualitative or mixed methods in design where qualitative data could be extracted and (2) report parental (age $>18$ years including mothers, fathers or primary caregivers) experiences of raising a child (aged 0-17 years) with a diagnosis of T1D. Studies were excluded if the child had a diagnosis of type 2 diabetes or had another comorbid long-term condition. Only studies in English were included and there was no restriction on publication date.

Eleven databases were systematically searched from their inception to May 2020 (Appendix 2 available at www.bjd-abcd.com). Articles were screened for relevance against the eligibility criteria at the title and abstract stage. The reasons for exclusion can be found in the PRISMA flow chart (Figure 1). Reference lists of the relevant studies were also searched for any additional research that may not have been captured by the original search.

To appraise the quality of the relevant studies, the Critical Appraisal Skills Programme (CASP) qualitative checklist was used. ${ }^{8}$ This was initially undertaken by the first author, with a subset of papers checked by the last author. No articles were excluded based on study quality.

Thematic synthesis ${ }^{9}$ was used to analyse and integrate the qualitative data, involving line-by-line inductive coding of the entire results section for each study. Codes were then collated and reviewed to examine for differences, patterns and similarities. This 
Figure 1. PRISMA flow diagram
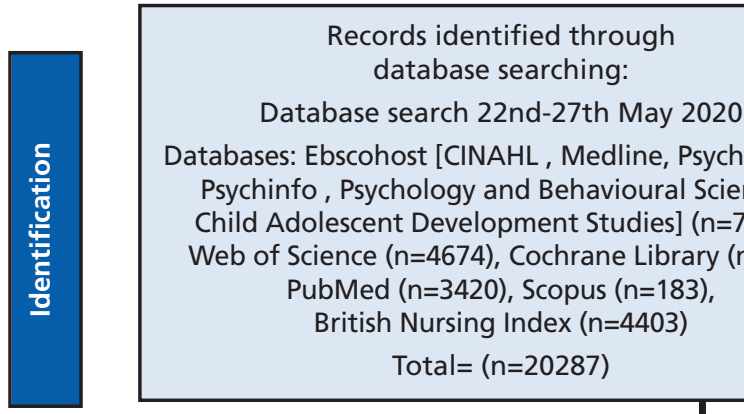

Databases: Ebscohost [CINAHL, Medline, Psycharticles, Psychinfo, Psychology and Behavioural Sciences, Child Adolescent Development Studies] ( $n=7553)$,

Web of Science $(n=4674)$, Cochrane Library $(n=54)$, PubMed $(n=3420)$, Scopus $(n=183)$, British Nursing Index $(n=4403)$ Total $=(n=20287)$

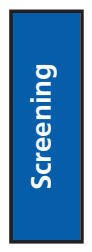

Records after duplicates removed $(n=7309)$
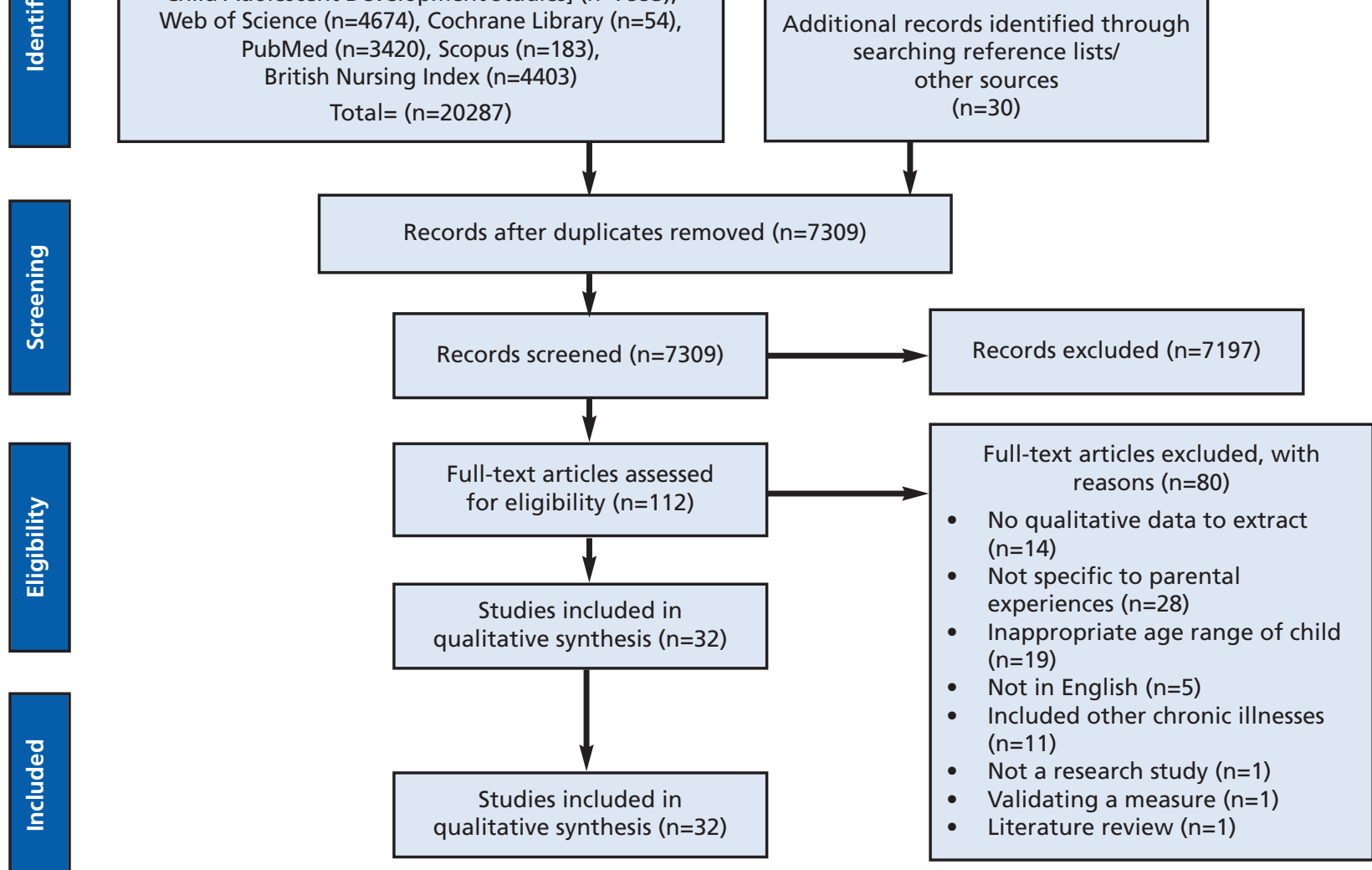

allowed the codes to be organised into groups for descriptive themes to be constructed. In order to address the research question and go beyond the content of the primary studies, analytical themes were then derived. The descriptive themes with illustrative quotations are detailed in Table 1.

\section{Results}

\section{Study characteristics and quality}

The systematic search yielded 7,309 results after duplicates were removed, with 32 studies published between 1995 and 2020 included (Figure 1). There were 1,417 participants across the 32 studies; 25 studies provided parents' gender, 526 of which were mothers $(72 \%)$ and 149 fathers (28\%). The ages of parents ranged from 22 to 58 years and the age of the child ranged from 2 to 17 years. Only seven studies reported on ethnicity, of which six reported that participants were either entirely or majority white. Studies were predominantly conducted in Europe $(n=16)$. The data collection methods varied but the predominant approach was interviews $(n=27)$ (Table 2$)$.

The 'relationship between researcher and participants being adequately considered' received the highest amount of 'unclear' scoring across the studies. All 32 studies were assessed as having a clear statement of the aims of the research (Q1) and qualitative methodology being appropriate (Q2). Overall, 26 of the 32 studies were judged as adequately reporting at least seven of the 10 CASP checklist items (Table 3).

\section{Thematic synthesis findings \\ Adjusting to a new reality}

This analytical theme reflects the new reality parents face whilst raising a child with T1D, beginning at diagnosis and involving changes to daily routines, dietary habits and learning new caregiving skills. This new reality influenced their decision-making about celebrations, family outings and future children. Parents were affected financially and emotionally, with the emotional impact starting at diagnosis. With time, parents became used to this new reality and it became part of daily life. This analytical theme is explored further below through the descriptive themes it was derived from: 'distressing diagnostic experience', 'change of life routine' and 'reconstruction of family dynamics'. 
Table 1 Qualitative synthesis: analytical themes, descriptive themes, example codes and illustrative quotations

\begin{tabular}{|c|c|c|c|}
\hline Analytical themes & Descriptive themes & Example codes & Illustrative quotations \\
\hline \multirow[t]{9}{*}{$\begin{array}{l}\text { Adjusting to a new } \\
\text { reality }\end{array}$} & $\begin{array}{l}\text { Distressing diagnostic } \\
\text { experience }\end{array}$ & $\begin{array}{l}\text { Interpretation of pre- } \\
\text { diagnostic/initial symptoms }\end{array}$ & $\begin{array}{l}\text { "I was determined it was a urine infection. I thought, no. It just } \\
\text { won't be diabetes. It's bound to be a urine infection" }{ }^{32}\end{array}$ \\
\hline & & $\begin{array}{l}\text { Blame game for cause of } \\
\text { diagnosis }\end{array}$ & $\begin{array}{l}\text { "I honestly went through what I might have done wrong ... You } \\
\text { somehow just imagine that you have caused the sickness, because } \\
\text { you have made some mistakes in the care of the child". }{ }^{17}\end{array}$ \\
\hline & & Emotional diagnostic reaction & $\begin{array}{l}\text { "I was shocked. I felt the world was finished for me. I could not } \\
\text { bear the conditions and I did not understand the things that they } \\
\text { were telling me". }{ }^{10}\end{array}$ \\
\hline & & Hospitalisation & $\begin{array}{l}\text { "We were at the hospital crying. My wife also thought it was } \\
\text { horrific, she was as shocked as I was. It makes me want to cry. } \\
\text { It was overwhelming, and a disaster telling my parents and my } \\
\text { daughter. I was bawling. It is a serious disease". }{ }^{23}\end{array}$ \\
\hline & & $\begin{array}{l}\text { Importance of routine/careful } \\
\text { planning }\end{array}$ & $\begin{array}{l}\text { "You can't just walk out the door like you used to be able to; you } \\
\text { have to plan things all the time. Basically the whole day revolves } \\
\text { around it, absolutely everything!" } 4\end{array}$ \\
\hline & & $\begin{array}{l}\text { Difficulties with insulin } \\
\text { administration }\end{array}$ & $\begin{array}{l}\text { "Applying insulin is a horror, it's a needle in our hearts when we } \\
\text { apply it. (Dedication) was a way to make me feel better too". }{ }^{3}\end{array}$ \\
\hline & & $\begin{array}{l}\text { Managing unpredictable blood } \\
\text { glucose readings }\end{array}$ & $\begin{array}{l}\text { "The child's level of blood glucose is a challenge to predict. Her } \\
\text { level of blood glucose has always been unpredictable-for } \\
\text { instance, it is high on a Monday morning, and then on Tuesday } \\
\text { and Wednesday, it is suddenly low, even though she eats the } \\
\text { same". }{ }^{13}\end{array}$ \\
\hline & & $\begin{array}{l}\text { Responsibility distribution/ } \\
\text { spousal support }\end{array}$ & $\begin{array}{l}\text { "So the (diabetes) nurse came and spoke properly to my husband } \\
\text { and told him he has to be a part of this because I can't do it by } \\
\text { myself ... he listened to what she was saying ... Yes, I'm glad that } \\
\text { he realises that he has to participate/we have decided that I'm } \\
\text { going to have some days off. When I have time off I really want to } \\
\text { feel like I have time off ... So we decided to have, one weekend is } \\
\text { daddy's weekend; one is mine and then a weekend when we are } \\
\text { all together. When he (the son) is sitting and eating he shows me } \\
\text { the pen and I say "Yes, but now daddy is sitting with you" "Yes, } \\
\text { but you must look." So I do take the largest part. And that is fine } \\
\text { by me; I do like to be in control of the situation". }{ }^{34}\end{array}$ \\
\hline & & Impact on siblings & $\begin{array}{l}\text { "The other one rebels against the sick child, feels jealous and even } \\
\text { anger and I still have to split them to avoid fighting. My other } \\
\text { daughter is jealous and keeps complaining that I don't like her, } \\
\text { but it is not like this, it is because the sick one deserves more care. } \\
\text { The other children even pretended to be sick to call my } \\
\text { attention". }{ }^{15}\end{array}$ \\
\hline
\end{tabular}

continued... 
Table 1 Qualitative synthesis: analytical themes, descriptive themes, example codes and illustrative quotations continued

\begin{tabular}{|c|c|c|c|}
\hline \multirow[t]{7}{*}{ Analytical themes } & Descriptive themes & Example codes & Illustrative quotations \\
\hline & & Sharing decision making & $\begin{array}{l}\text { "We would ask the other what would you give her and then we } \\
\text { would compare answers and if we were off a bit we kind of } \\
\text { averaged them. So, we had to come up with our own little thing } \\
\text { to make sure we were doing it right. God forbid you felt you } \\
\text { made a mistake and the kid went low that day ...". }{ }^{25}\end{array}$ \\
\hline & & Issues of independence & $\begin{array}{l}\text { "The main difference has been ... he's just the last year or so been } \\
\text { at the age where you're letting go ... they can make decisions ... } \\
\text { go into town and things. And suddenly, you're having to come } \\
\text { back in again as the vigilant parent. It sort of collides with the } \\
\text { emerging independence. And working out how to manage that } \\
\text { and allow him to carry on becoming more and more independent } \\
\text { is quite a juggling act". }{ }^{32}\end{array}$ \\
\hline & Psychological impact & Emotional impact & $\begin{array}{l}\text { "I went into a total depression Even [my husband] couldn't } \\
\text { understand how I felt. It was frightening; I actually had suicidal } \\
\text { thoughts. I was driving across the bridge. [My toddler with } \\
\text { diabetes] was with me and I suddenly thought I can't go on with } \\
\text { all this. I had this desire to drive into the oncoming traffic and end } \\
\text { it all. The feeling came back several times so I went for help. It } \\
\text { was frightening". }{ }^{0}\end{array}$ \\
\hline & & Night-time anxiety & $\begin{array}{l}\text { "... I still have nightly anxiety as I cannot truly rely on the levels as } \\
\text { I could before, as puberty has started and the remission is all } \\
\text { gone; thus, I have to adjust the dosages considerably more exactly } \\
\text { and monitor the blood sugar more often ....". }{ }^{36}\end{array}$ \\
\hline & & Fear of hypoglycaemia & $\begin{array}{l}\text { "Every time that she does get near a hypo, when her figures are } \\
\text { low, I do find myself, maybe I don't show it as much, but deep } \\
\text { down I do have a bit of a panic attack thinking this could lead into } \\
\text { something else. Is she going to collapse?" } 33\end{array}$ \\
\hline & & Worries about the future & $\begin{array}{l}\text { 'I am always thinking about his future. I wonder what will happen } \\
\text { to his body. Can he be successful in his life? I do not know; the } \\
\text { future is unclear". }{ }^{31}\end{array}$ \\
\hline \multirow{4}{*}{$\begin{array}{l}\text { Navigating } \\
\text { appropriate T1D } \\
\text { support }\end{array}$} & & $\begin{array}{l}\text { Others' inappropriate diabetes } \\
\text { management }\end{array}$ & $\begin{array}{l}\text { "We had an incident last Friday where he was the student of the } \\
\text { month. He got to go to this party with all these kids, and he was } \\
\text { told that he couldn't have a snack, basically because he's diabetic. } \\
\text { That happens all the time to him, and it's really hard to explain to } \\
\text { a seven-year-old [...] Why couldn't they just call me and say, "Hey, } \\
\text { can he have a snack?" That's one of the harder things, because } \\
\text { people don't understand how it makes him feel".12 }\end{array}$ \\
\hline & & Reduced social contact & $\begin{array}{l}\text { "Slowly, people visiting became less and sympathies became by } \\
\text { telephone. As everyone was busy with their own lives". }{ }^{10}\end{array}$ \\
\hline & & Difficult clinic experiences & $\begin{array}{l}\text { "I often feel stressed up to about a week before I go to clinic. I } \\
\text { worry about what my son's HbA } 1 \text { c results will be. I start to feel } \\
\text { like I have not done enough to make sure his blood sugars have } \\
\text { been stable. I sometimes feel under confident in my ability to treat } \\
\text { and care for my son. I feel a poor blood test at clinic reflects on } \\
\text { my care and ability".22 }\end{array}$ \\
\hline & & $\begin{array}{l}\text { Importance of diabetes } \\
\text { community }\end{array}$ & $\begin{array}{l}\text { "Being involved in the diabetes community led to forming new } \\
\text { friendships and deriving meaning from advocacy efforts". } 1\end{array}$ \\
\hline
\end{tabular}

T1D, type 1 diabetes mellitus 
Table 2 Study characteristics

\begin{tabular}{|c|c|c|c|c|c|}
\hline $\begin{array}{l}\text { Study (author, } \\
\text { year, country) }\end{array}$ & Aim & Participants & $\begin{array}{l}\text { Data collection } \\
\text { method }\end{array}$ & Data analysis & Key findings \\
\hline $\begin{array}{l}\text { Khandan et al } \\
(2018)^{17} \\
\text { Iran }\end{array}$ & $\begin{array}{l}\text { To explore mothers' } \\
\text { experiences in the maze } \\
\text { path to the diagnosis of } \\
\text { children's disease }\end{array}$ & $\begin{array}{l}15 \text { mothers with } \\
\text { children (aged } \leq 14 \\
\text { years) who suffered } \\
\text { from T1D and at } \\
\text { least one year had } \\
\text { passed since } \\
\text { diabetes was } \\
\text { detected in their } \\
\text { children }\end{array}$ & $\begin{array}{l}\text { Semi- } \\
\text { structured interviews }\end{array}$ & Content analysis & $\begin{array}{l}\text { Themes: } \\
\text { Entanglement in the maze path } \\
\text { of the disease diagnosis } \\
\text { Facing the reality of the } \\
\text { child's disease } \\
\text { To grin and bear with new } \\
\text { conditions }\end{array}$ \\
\hline $\begin{array}{l}\text { Albolhassani et al } \\
(2013)^{18} \\
\text { Iran }\end{array}$ & $\begin{array}{l}\text { Explore mothers' } \\
\text { experience of children } \\
\text { with diabetes }\end{array}$ & $\begin{array}{l}11 \text { mothers } 28-42 \\
\text { years. Children } \\
\text { aged } 4-16 . \text { All } \\
\text { participants married }\end{array}$ & Interviews & Content analysis & $\begin{array}{l}\text { Themes: } \\
\text { Reaction at time of diagnosis: } \\
\text { denial, shock, presentiment, } \\
\text { concern, anger, anxiety, } \\
\text { impatience and crying, lack of } \\
\text { info, lack of attention to their } \\
\text { needs, lack of enough } \\
\text { opportunities to accept the } \\
\text { disease } \\
\text { Disease consequences for } \\
\text { mothers: living with uncertainty } \\
\text { and concern, trust in God and } \\
\text { spiritual connection, false hope. }\end{array}$ \\
\hline $\begin{array}{l}\text { Anderson et al } \\
(2018)^{2} \\
\text { Jamaica }\end{array}$ & $\begin{array}{l}\text { Determine the challenges, } \\
\text { coping strategies and needs } \\
\text { of urban and rural Jamaican } \\
\text { caregivers of adolescents } \\
\text { with diabetes, and suggest } \\
\text { ways to assist coping }\end{array}$ & $\begin{array}{l}19 \text { caregivers of } \\
\text { adolescents with } \\
\text { diabetes. } \\
\text { Adolescents aged } \\
\text { 12-17 }\end{array}$ & Focus groups & Thematic analysis & $\begin{array}{l}\text { Main challenges caregivers } \\
\text { faced were keeping their } \\
\text { children healthy, managing } \\
\text { conflict with their children, and } \\
\text { financial concerns. They met } \\
\text { these challenges with problem- } \\
\text { focused and emotion-focused } \\
\text { coping strategies }\end{array}$ \\
\hline $\begin{array}{l}\text { Sullivan-Bolyai } \\
\text { et al }(2003)^{5} \\
\text { UK }\end{array}$ & $\begin{array}{l}\text { Describe the day-to-day } \\
\text { experiences of mothers } \\
\text { raising young children }<4 \\
\text { years with T1D }\end{array}$ & $\begin{array}{l}\text { Sample of } 28 \\
\text { English-speaking } \\
\text { mothers of children } \\
<4 \text { years of age } \\
\text { diagnosed with T1D } \\
\text { for at least } 3 \text { months }\end{array}$ & $\begin{array}{l}\text { Descriptive, } \\
\text { naturalistic inquiry } \\
\text { interview }\end{array}$ & $\begin{array}{l}\text { Descriptive, } \\
\text { naturalistic inquiry } \\
\text { principles }\end{array}$ & $\begin{array}{l}\text { Constant vigilance: } 3 \text { aspects of } \\
\text { constant vigilance: day-to-day } \\
\text { concerns, day-to-day manage- } \\
\text { ment, and supportive resources. } \\
\text { Burden of Constant Vigilance } \\
\text { on Mothers' Physical and } \\
\text { Emotional Health }\end{array}$ \\
\hline $\begin{array}{l}\text { Pimentel et al } \\
(2017)^{3} \\
\text { Brazil }\end{array}$ & $\begin{array}{l}\text { To understand the } \\
\text { perception of parents of } \\
\text { children and adolescents in } \\
\text { relation to the diagnosis of } \\
\text { T1D }\end{array}$ & $\begin{array}{l}11 \text { parents of } \\
\text { children and } \\
\text { adolescents with } \\
\text { T1D }\end{array}$ & $\begin{array}{l}\text { Semi-structured } \\
\text { questionnaire }\end{array}$ & Content analysis & $\begin{array}{l}\text { Experiencing the diagnosis and } \\
\text { being transformed by the } \\
\text { disease of the child }\end{array}$ \\
\hline
\end{tabular}


Table 2 Study characteristics continued

\begin{tabular}{|c|c|c|c|c|c|}
\hline $\begin{array}{l}\text { Study (author, } \\
\text { year, country) }\end{array}$ & Aim & Participants & $\begin{array}{l}\text { Data collection } \\
\text { method }\end{array}$ & Data analysis & Key findings \\
\hline $\begin{array}{l}\text { Haslund-Thomsen } \\
\text { et al }(2020)^{20} \\
\text { Denmark }\end{array}$ & $\begin{array}{l}\text { To explore parents' } \\
\text { experience of having a child } \\
\text { aged } 4-9 \text { years with T1D } \\
\text { using continuous glucose } \\
\text { monitoring (CGM) }\end{array}$ & $\begin{array}{l}\text { Danish-speaking } \\
\text { parents of children } \\
\text { with T1D aged } \\
4-9 \text { years who } \\
\text { receive care and } \\
\text { treatment at the } \\
\text { diabetes units }\end{array}$ & $\begin{array}{l}\text { Semi-structured } \\
\text { interviews }\end{array}$ & Thematic analysis & $\begin{array}{l}\text { (1) Living in the context of the } \\
\text { unpredictability of diabetes. } \\
\text { (2) Establishing a sense of } \\
\text { control and security with CGM. } \\
\text { (3) Learning to use and trust } \\
\text { CGM and educating other } \\
\text { caregivers }\end{array}$ \\
\hline $\begin{array}{l}\text { Povlsen et al } \\
(2009)^{21} \\
\text { Denmark and } \\
\text { Egypt }\end{array}$ & $\begin{array}{l}\text { To explore variations in how } \\
\text { parents living as immigrants } \\
\text { in Denmark and in their } \\
\text { native country had } \\
\text { perceived learning to live } \\
\text { with a child with diabetes }\end{array}$ & $\begin{array}{l}\text { Arabic-speaking } \\
\text { parents, who had } \\
\text { immigrated to } \\
\text { Denmark, where } \\
\text { their child had } \\
\text { been diagnosed } \\
\text { with diabetes, } \\
\text { were matched } \\
\text { with Arabic- } \\
\text { speaking parents } \\
\text { living in their } \\
\text { native country } \\
\text { (Egypt). The } \\
\text { children were } \\
7-16 \text { years old } \\
\text { and all had T1D }\end{array}$ & $\begin{array}{l}\text { Semi-structured } \\
\text { interviews }\end{array}$ & $\begin{array}{l}\text { Phenomeno-graphic } \\
\text { approach }\end{array}$ & $\begin{array}{l}\text { Disease's influence } \\
\text { on the family situation: } \\
\text { Shock and disaster } \\
\text { Change in parental roles } \\
\text { Change in social relations } \\
\text { Learning about diabetes } \\
\text { management: } \\
\text { Professional education and } \\
\text { support } \\
\text { Search for additional } \\
\text { knowledge } \\
\text { Future prospects for the child: } \\
\text { Anxiety } \\
\text { Faith and hope }\end{array}$ \\
\hline $\begin{array}{l}\text { Martins et al } \\
(2014)^{22} \\
\text { Brazil }\end{array}$ & $\begin{array}{l}\text { To understand the } \\
\text { experience of mothers in } \\
\text { the care of the child with } \\
\text { T1D in a unit of Tertiary } \\
\text { Reference in Diabetes }\end{array}$ & $\begin{array}{l}12 \text { mothers of } \\
\text { children with T1D } \\
\text { participated }\end{array}$ & $\begin{array}{l}\text { Semi-structured } \\
\text { interview }\end{array}$ & Content analysis & $\begin{array}{l}\text { Multiple feeling generated in } \\
\text { the impact of the diagnosis; } \\
\text { mother facing the competitive- } \\
\text { ness of affection among the } \\
\text { children, experience of the } \\
\text { mother in the expansion of } \\
\text { the locus daily care }\end{array}$ \\
\hline $\begin{array}{l}\text { Seppänen et al } \\
(1999)^{24} \\
\text { Finland }\end{array}$ & $\begin{array}{l}\text { Describe and understand } \\
\text { the parental coping and } \\
\text { social support received by } \\
\text { the parents of diabetic } \\
\text { children }\end{array}$ & $\begin{array}{l}\text { Two sets of } \\
\text { parents of two } \\
\text { girls ( } 3 \text { and } 4 \text { years } \\
\text { old) admitted into } \\
\text { hospital because } \\
\text { of diagnosed } \\
\text { diabetes. Parents } \\
\text { aged 35-40 years }\end{array}$ & $\begin{array}{l}\text { Interview and } \\
\text { observation }\end{array}$ & $\begin{array}{l}\text { Time series and } \\
\text { content analysis }\end{array}$ & $\begin{array}{l}\text { Six phases of parental coping } \\
\text { were identified: disbelief, lack of } \\
\text { information and guilt, learning } \\
\text { to care, normalisation, uncer- } \\
\text { tainty and reorganisation. In the } \\
\text { different phases of parental } \\
\text { coping, the parents' experience } \\
\text { of stress, coping strategies and } \\
\text { sense of control varied }\end{array}$ \\
\hline $\begin{array}{l}\text { Lawton et al } \\
(2014)^{25} \\
\text { UK }\end{array}$ & $\begin{array}{l}\text { To explore the difficulties } \\
\text { parents encounter in trying } \\
\text { to achieve clinically } \\
\text { recommended blood } \\
\text { glucose levels and how they } \\
\text { could be better supported } \\
\text { to optimise their child's } \\
\text { glycaemic control }\end{array}$ & $\begin{array}{l}54 \text { parents of } \\
\text { children with T1D } \\
\text { ( } \leq 12 \text { years) }\end{array}$ & Interviews & Thematic analysis & $\begin{array}{l}\text { Fear of hypoglycaemia, } \\
\text { monitoring and supervision, } \\
\text { school/nursery and other } \\
\text { settings outside the home, } \\
\text { cocooning versus } \\
\text { accommodating a 'normal' } \\
\text { childhood, 'home' and 'away' } \\
\text { targets, experiences of } \\
\text { consultations and support needs } \\
\text { continued... }\end{array}$ \\
\hline
\end{tabular}


Table 2 Study characteristics continued

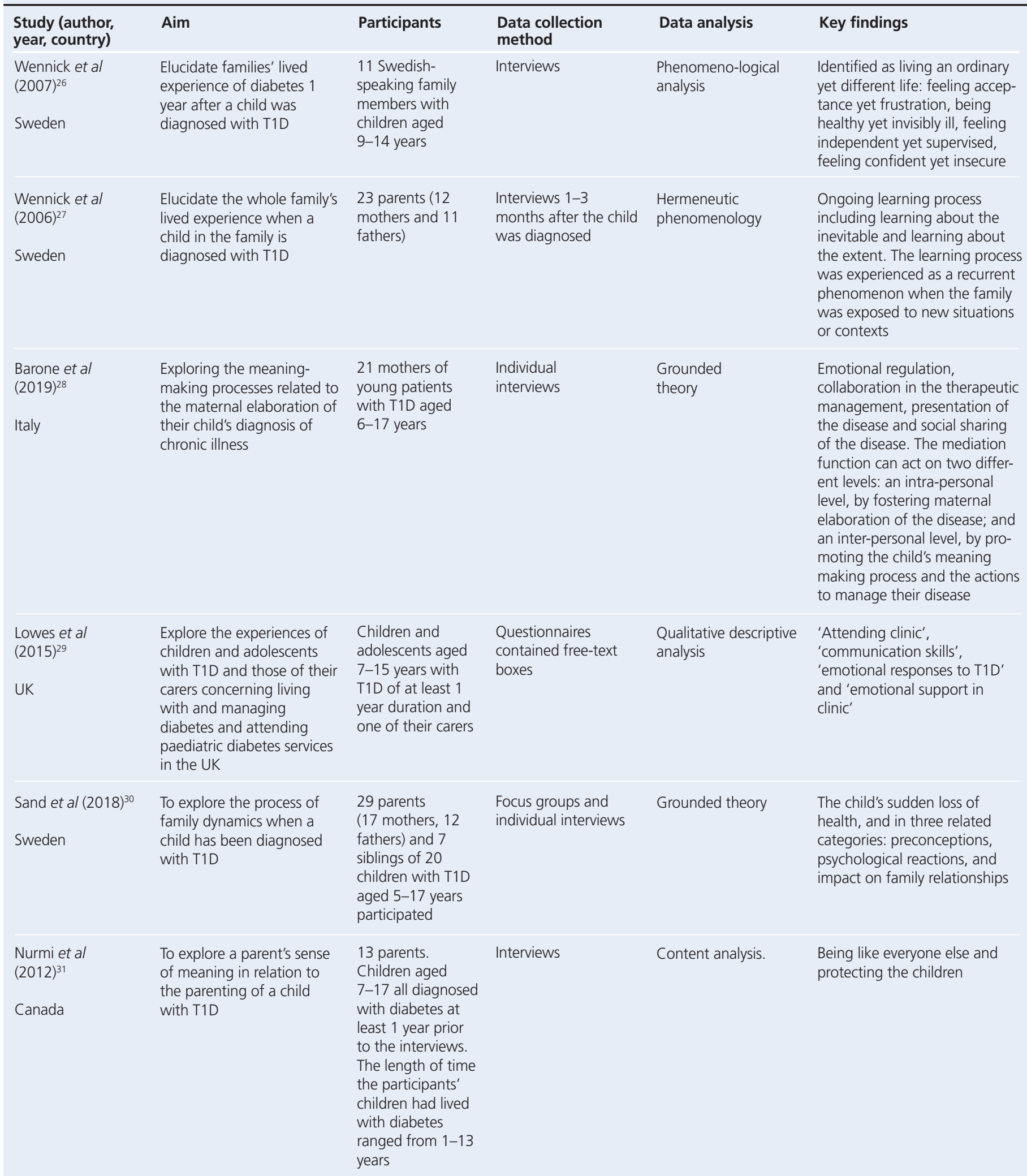


Table 2 Study characteristics

\begin{tabular}{|c|c|c|c|c|c|}
\hline $\begin{array}{l}\text { Study (author, } \\
\text { year, country) }\end{array}$ & Aim & Participants & $\begin{array}{l}\text { Data collection } \\
\text { method }\end{array}$ & Data analysis & Key findings \\
\hline $\begin{array}{l}\text { Symons et al } \\
(2015)^{4} \\
\text { New Zealand }\end{array}$ & $\begin{array}{l}\text { To improve health } \\
\text { professionals' } \\
\text { understanding of the } \\
\text { impact on families of living } \\
\text { with a child diagnosed with } \\
\text { T1D. The study gives voice } \\
\text { to parents of children } \\
\text { diagnosed with T1D, } \\
\text { providing an opportunity } \\
\text { for them to speak of their } \\
\text { experiences and convey the } \\
\text { realities, challenges and } \\
\text { struggles of everyday life } \\
\text { caring for a child with this } \\
\text { condition }\end{array}$ & $\begin{array}{l}\text { Nine parents/ } \\
\text { caregivers of a } \\
\text { child, aged 4-14 } \\
\text { years who had } \\
\text { been diagnosed } \\
\text { with T1D at least } \\
12 \text { months } \\
\text { previously }\end{array}$ & $\begin{array}{l}\text { Semi-structured } \\
\text { interviews }\end{array}$ & Thematic analysis & $\begin{array}{l}\text { Disruption to family life; impact } \\
\text { on family relationships; } \\
\text { psychosocial effects of living } \\
\text { with T1D; and adaptation to a } \\
\text { 'new normal' }\end{array}$ \\
\hline $\begin{array}{l}\text { Rifshana et al } \\
(2017)^{33} \\
\text { New Zealand }\end{array}$ & $\begin{array}{l}\text { To add to the literature on } \\
\text { embodiment within care- } \\
\text { giving by exploring the lived } \\
\text { experience of parents of } \\
\text { children with T1D }\end{array}$ & $\begin{array}{l}17 \text { parents ( } 14 \\
\text { mothers and } 3 \\
\text { fathers) of children } \\
\text { aged } 4-12 \text { years } \\
\text { who had been } \\
\text { diagnosed with } \\
\text { T1D for a mini- } \\
\text { mum of } 6 \text { months }\end{array}$ & $\begin{array}{l}\text { Semi-structured } \\
\text { interviews }\end{array}$ & IPA & $\begin{array}{l}\text { Prominent theme: Looking after } \\
\text { a child with diabetes: 'Issues of } \\
\text { embodiment'. } \\
\text { Two specific aspects of this } \\
\text { main theme: 'Constant vigi- } \\
\text { lance and careful management' } \\
\text { and 'Comparing diabetes with } \\
\text { other condition' }\end{array}$ \\
\hline
\end{tabular}

continued... 
Table 2 Study characteristics continued

\begin{tabular}{|c|c|c|c|c|c|}
\hline $\begin{array}{l}\text { Study (author, } \\
\text { year, country) }\end{array}$ & Aim & Participants & $\begin{array}{l}\text { Data collection } \\
\text { method }\end{array}$ & Data analysis & Key findings \\
\hline $\begin{array}{l}\text { Sullivan-Bolyai } \\
\text { et al }(2006)^{34} \\
\text { USA }\end{array}$ & $\begin{array}{l}\text { To describe fathers' } \\
\text { experiences in parenting } \\
\text { and managing the care } \\
\text { of their young children with } \\
\text { T1D }\end{array}$ & $\begin{array}{l}14 \text { fathers of } 15 \\
\text { children with T1D. } \\
\text { Of the } 15 \text { children } \\
\text { ( } 2 \text { were siblings), } 9 \\
\text { were male and } 6 \\
\text { female. Their } \\
\text { mean age was } \\
5 \pm 2 \text { years (range } \\
2-8 \text { years) and } \\
\text { mean duration of } \\
\text { illness was } 1.4 \pm 0.8 \\
\text { months (range } 2 \\
\text { weeks to } 3 \text { years) }\end{array}$ & Interviews & $\begin{array}{l}\text { Naturalistic inquiry } \\
\text { and content analysis }\end{array}$ & $\begin{array}{l}\text { "From sadness to action" with } \\
6 \text { categories emerging: } \\
\text { (1) "shock and awe" (after } \\
\text { diagnosis); (2) quick response to } \\
\text { the diagnosis and learning } \\
\text { diabetes care: "suck it up and } \\
\text { do it"; ( } 3 \text { ) "staying in the } \\
\text { loop" (practising the skills, tasks } \\
\text { and responsibilities of diabetes } \\
\text { management); } \\
\text { (4) "partnerships in care" (tag } \\
\text { teaming or co-parenting); } \\
\text { (5) active participation (being } \\
\text { actively involved in their } \\
\text { children's day-to-day care and } \\
\text { benefiting from participating in } \\
\text { this care); and (6) mantra for } \\
\text { living with diabetes: child first, } \\
\text { diabetes second }\end{array}$ \\
\hline $\begin{array}{l}\text { Lowes et al } \\
(2005)^{35} \\
\text { UK) }\end{array}$ & $\begin{array}{l}\text { To explore parents' } \\
\text { experiences of } \\
\text { having a child diagnosed } \\
\text { T1D and their adjustment } \\
\text { and adaptation over the } \\
\text { first year }\end{array}$ & $\begin{array}{l}38 \text { parents, } \\
\text { including two } \\
\text { single-parent } \\
\text { families. Median } \\
\text { age } 39 \text { years } \\
\text { (range 23-49). } \\
\text { Median age of } \\
\text { their newly diag- } \\
\text { nosed children (11 } \\
\text { boys and } 9 \text { girls) } \\
\text { was } 9 \text { years (range } \\
\text { 2-15). Three } \\
\text { parents had T1D. } \\
\text { Four parents had } \\
\text { another family } \\
\text { member with T1D } \\
\text { or T2DM }\end{array}$ & Interviews & $\begin{array}{l}\text { Unclear/Framework } \\
\text { of the Theory of } \\
\text { Psychosocial Transition }\end{array}$ & $\begin{array}{l}\text { Before diagnosis, most parents } \\
\text { associated their child's } \\
\text { symptoms with normal } \\
\text { childhood illnesses. The } \\
\text { unexpectedness and speed of } \\
\text { the diagnosis left all parents } \\
\text { ill-prepared to deal with the } \\
\text { situation. Their world suddenly } \\
\text { changed, leaving them insecure } \\
\text { and uncertain about the future. } \\
\text { Diabetes intruded emotionally } \\
\text { and practically upon all of their } \\
\text { lives. Parents successfully } \\
\text { adjusted and adapted their lives } \\
\text { and rebuilt a new model of the } \\
\text { world to accommodate their } \\
\text { child's diabetes. However, this } \\
\text { dynamic process has no } \\
\text { guaranteed endpoint for } \\
\text { parents }\end{array}$ \\
\hline $\begin{array}{l}\text { Spencer et al } \\
(2012)^{36} \\
\text { UK }\end{array}$ & $\begin{array}{l}\text { To explore adolescents' and } \\
\text { parents' experiences of } \\
\text { living with T1D from an } \\
\text { interpretive } \\
\text { phenomenological } \\
\text { perspective }\end{array}$ & $\begin{array}{l}20 \text { adolescents (9 } \\
\text { male, } 11 \text { female) } \\
\text { with T1D and } 27 \\
\text { parents ( } 7 \text { male, } \\
20 \text { female); all } \\
\text { were white British }\end{array}$ & Interviews & IPA & $\begin{array}{l}\text { Stage 1: adapting to the } \\
\text { diagnosis } \\
\text { Stage 2: learning to live with } \\
\text { diabetes } \\
\text { Stage 3: gaining independence }\end{array}$ \\
\hline $\begin{array}{l}\text { Hatton et al } \\
(1995)^{37} \\
\text { Canada }\end{array}$ & $\begin{array}{l}\text { To gain knowledge and } \\
\text { understanding of the } \\
\text { parents' experiences }\end{array}$ & $\begin{array}{l}8 \text { two-parent } \\
\text { families with an } \\
\text { infant or toddler } \\
\text { with diabetes, } \\
\text { who had been } \\
\text { managing the } \\
\text { child's diabetes for } \\
\text { a minimum of } 2 \\
\text { months. The } \\
\text { children with } \\
\text { diabetes ranged in } \\
\text { age from } 5 \text { weeks } \\
\text { to } 31 \text { months at } \\
\text { time of diagnosis, } \\
\text { with an average } \\
\text { age of } 18 \text { months }\end{array}$ & Interviews & $\begin{array}{l}\text { Phenomenological } \\
\text { analytical procedures }\end{array}$ & $\begin{array}{l}\text { Diagnosis and child's } \\
\text { hospitalisation, adjusting to } \\
\text { care at home, and long-term } \\
\text { adaptation. Within these } \\
\text { phases, parents described } \\
\text { inordinate amounts of stress } \\
\text { exacerbated by the child's } \\
\text { young age and the complex } \\
\text { intrusive nature of diabetes } \\
\text { management }\end{array}$ \\
\hline
\end{tabular}


Table 2 Study characteristics continued

\begin{tabular}{|c|c|c|c|c|c|}
\hline $\begin{array}{l}\text { Study (author, } \\
\text { year, country) }\end{array}$ & Aim & Participants & $\begin{array}{l}\text { Data collection } \\
\text { method }\end{array}$ & Data analysis & Key findings \\
\hline $\begin{array}{l}\text { Khandan et al } \\
(2018)^{38} \\
\text { Iran }\end{array}$ & $\begin{array}{l}\text { To explore the experiences } \\
\text { of diabetic children's } \\
\text { mothers from the transfer } \\
\text { of caring role }\end{array}$ & $\begin{array}{l}11 \text { Iranian mothers } \\
\text { of children aged } \\
\leq 14 \text { years with } \\
\text { T1D }\end{array}$ & $\begin{array}{l}\text { Semi-structured } \\
\text { interviews }\end{array}$ & $\begin{array}{l}\text { Phenomenological } \\
\text { method }\end{array}$ & $\begin{array}{l}\text { 'Facing the care management } \\
\text { challenges,' 'care in the shadow } \\
\text { of concern', and 'hard life in } \\
\text { the impasse of diabetes' }\end{array}$ \\
\hline $\begin{array}{l}\text { Lowes et al } \\
(2004)^{39} \\
\text { UK }\end{array}$ & $\begin{array}{l}\text { To explore parents' } \\
\text { experience of having a child } \\
\text { diagnosed with T1D } \\
\text { managed at home and their } \\
\text { first year following } \\
\text { diagnosis }\end{array}$ & $\begin{array}{l}38 \text { parents. All } \\
\text { parents were } \\
\text { white English- } \\
\text { speaking. Their } \\
\text { median age was } \\
39 \text { (range 23-49) } \\
\text { years and the } \\
\text { median age of } \\
\text { their newly } \\
\text { diagnosed children } \\
\text { (11 boys, } 9 \text { girls) } \\
\text { was } 9 \text { (range } \\
2-15) \text { years }\end{array}$ & Interviews & Unclear/thematic & $\begin{array}{l}\text { Many parents were alarmed by } \\
\text { the speed of diagnosis } \\
\text { following the gradual progress } \\
\text { of their child's symptoms. The } \\
\text { provision of timely adequate } \\
\text { information was important to } \\
\text { all parents. Although five } \\
\text { parents had initial concerns } \\
\text { about going home, all parents } \\
\text { were subsequently pleased their } \\
\text { children had not been } \\
\text { hospitalised. Home } \\
\text { management enabled parents } \\
\text { to integrate diabetes } \\
\text { management into the family's } \\
\text { normal lifestyle from diagnosis. } \\
\text { Professional support, } \\
\text { particularly accessible telephone } \\
\text { advice, was valued by and } \\
\text { reassured parents. Parents } \\
\text { experienced a loss of } \\
\text { spontaneity, a continuing fear } \\
\text { of hypoglycaemia and did not } \\
\text { want their child to feel different } \\
\text { to other children. Acutely } \\
\text { aware of the seriousness of } \\
\text { diabetes, they did their utmost } \\
\text { to achieve optimal glycaemic } \\
\text { control but felt that diabetes } \\
\text { could not 'dominate' if they } \\
\text { were to lead a 'normal' life }\end{array}$ \\
\hline $\begin{array}{l}\text { Sparud-Lundin } \\
\text { et al }(2013)^{41} \\
\text { Sweden }\end{array}$ & $\begin{array}{l}\text { To explore parents' process } \\
\text { of changes and challenges } \\
\text { in their patterns of daily } \\
\text { activities after the onset of } \\
\text { diabetes in a child }\end{array}$ & $\begin{array}{l}36 \text { parents } \\
\text { involved and their } \\
\text { children, } 21 \\
\text { mothers and } 15 \\
\text { fathers of } 23 \\
\text { children with T1D } \\
\text { 8-10 months after } \\
\text { onset }\end{array}$ & Interviews & $\begin{array}{l}\text { Qualitative } \\
\text { comparative analysis }\end{array}$ & $\begin{array}{l}\text { The core category depicts how } \\
\text { the illness forced parents to } \\
\text { reconstruct their family project } \\
\text { with respect to patterns of daily } \\
\text { activities and gender structures. } \\
\text { The emerging subcategories of } \\
\text { reinforced mothering and } \\
\text { adjusted fathering illustrate the } \\
\text { parents' effort to handle } \\
\text { contemporary and } \\
\text { contradictory demands }\end{array}$ \\
\hline
\end{tabular}

continued... 
Table 2 Study characteristics continued

\begin{tabular}{|c|c|c|c|c|c|}
\hline $\begin{array}{l}\text { Study (author, } \\
\text { year, country) }\end{array}$ & Aim & Participants & $\begin{array}{l}\text { Data collection } \\
\text { method }\end{array}$ & Data analysis & Key findings \\
\hline $\begin{array}{l}\text { Smith et al } \\
(2010)^{42} \\
\text { USA }\end{array}$ & $\begin{array}{l}\text { Examined child and parent } \\
\text { perceptions of the child and } \\
\text { parent roles in diabetes } \\
\text { management as well as the } \\
\text { child's attitude toward his } \\
\text { or her diabetes }\end{array}$ & $\begin{array}{l}49 \text { mothers, } \\
6 \text { fathers and } 4 \\
\text { guardians of } \\
\text { children with T1D. } \\
60 \text { children ( } 22 \\
\text { boys and } 36 \text { girls). } \\
\text { Children ranged in } \\
\text { age from } 8 \text { years } 6 \\
\text { months to } 15 \\
\text { years } 8 \text { months } \\
\text { (M=12 years } 2 \\
\text { months; SD=2 } \\
\text { years } 1 \text { month) }\end{array}$ & Interviews & $\begin{array}{l}\text { Grounded Theory } \\
\text { Approach }\end{array}$ & $\begin{array}{l}\text { Themes: daily activities, } \\
\text { Forgetting, having difficulty, } \\
\text { being on the pump }\end{array}$ \\
\hline $\begin{array}{l}\text { Wennick et al } \\
(2009)^{43} \\
\text { Sweden }\end{array}$ & $\begin{array}{l}\text { To illuminate family } \\
\text { members' everyday } \\
\text { experiences } 3 \text { years after a } \\
\text { child had been diagnosed } \\
\text { with T1D }\end{array}$ & $\begin{array}{l}9 \text { fathers aged } \\
33-54 \text { years } \\
\text { (median } 45 \text { years) } \\
\text { and } 11 \text { mothers } \\
\text { aged } 33-48 \text { years } \\
\text { (median } 43 \text { years) }\end{array}$ & Individual interviews & Content analysis & $\begin{array}{l}\text { Eight categories were identified } \\
\text { to describe the families' every- } \\
\text { day experience: (a) knowledge } \\
\text { and tried experience give skills; } \\
\text { (b) capricious blood sugar level; } \\
\text { (c) ambivalent parenthood; } \\
\text { (d) stressful daily planning; } \\
\text { (e) physical activity as pleasure } \\
\text { and annoyance; (f) fear of } \\
\text { losing control; (g) a private and } \\
\text { public concern; and (h) needed } \\
\text { and not needed medical service }\end{array}$ \\
\hline
\end{tabular}

\section{Distressing diagnostic experience}

This theme was present in 20 of the 32 primary studies which represents $63 \%$ of the studies (Table 4). Parents reported a distressing diagnostic experience that brought up a range of unsettling emotions such as shock, disbelief, anger, stress, anxiety, grief and sadness. Some parents were overwhelmed and tearful at diagnosis, describing it as extremely painful and traumatic. Some of the shock at diagnosis was explained as being due to the lack of understanding of T1D, incorrectly assuming this was not a condition which affected children. Parents experienced guilt at not noticing symptoms and often blamed themselves for T1D; trying to pinpoint the cause through examining their care of the child. The route to diagnosis was not always straightforward; reasons included misdiagnosis by doctors, parents not recognising T1D symptoms or attributing symptoms to other common conditions, which sometimes resulted in delaying seeking medical support. In some situations this delay in receiving an accurate and timely diagnosis led to the child's health deteriorating to the point of hospitalisation, which was distressing for parents. Parents had difficulty initially accepting the diagnosis although most came to terms with the diagnosis with time.

\section{Change of life routine after diagnosis}

This theme was present in 27 of the 32 primary studies which represents $84 \%$ of the studies (Table 4). Parents described a change of life routine after receiving the diagnosis that involved complex T1D management. Parents expressed concerns about their ability to be able to care and cope with the complex regimens. Parents learnt multiple new T1D-related caregiving skills such as administering insulin and understanding behavioural cues that may indicate hyperglycemia or hypoglycemia, which could change as the child developed. For example, one parent described that their child would be argumentative when their bloods were high and go very pale when their bloods were low. Parents struggled with the unpredictability of T1D, specifically around blood glucose levels. This unpredictability resulted in parents closely monitoring their children and blood glucose levels. Parents described the incessant nature of managing the disease and the time-consuming day-to-day responsibilities. Parents experienced a loss of spontaneity and flexibility in their daily routine as planning was always required, especially with food and play or activities. There were financial implications of raising a child with T1D, whether this was from a dietary perspective of buying sugar free/low sugar food, or through T1D care such as insulin and diabetes-related supplies. The cost of T1D care was a particular concern for those parents who did not have adequate funding for this through their country's healthcare/insurance. This was prevalent in seven studies which were undertaken in Jamaica, Brazil, Egypt, Ghana, Iran and USA.

Parents' employment was also impacted, with some parents taking on more work to cover the cost of T1D treatment and others having to give up work or change to part-time because of managing T1D care, such as frequent doctors' appointments. Dietary requirements were described as complicating celebrations such as birthday parties or family meals out. After time, parents reported the change in life routine being a new normal and part of daily life. 
Table 3 Critical Appraisal Skills Programme Qualitative Checklist

\begin{tabular}{|c|c|c|c|c|c|c|c|c|c|c|c|}
\hline First author and year & Q1 & Q2 & Q3 & Q4 & Q5 & Q6 & Q7 & Q8 & Q9 & Q10 & $\begin{array}{l}\text { 'Y' total for } \\
\text { each study }\end{array}$ \\
\hline Khandan et al (2018) ${ }^{17}$ & Y & Y & Y & Y & Y & C & $C$ & Y & Y & Y & $8 / 10$ \\
\hline Albolhassani et al (2013) ${ }^{18}$ & Y & Y & Y & Y & Y & Y & Y & Y & Y & Y & $10 / 10$ \\
\hline Anderson et al (2018) & Y & Y & C & Y & Y & C & Y & Y & Y & Y & $8 / 10$ \\
\hline Commissariat et al $(2020)^{19}$ & Y & Y & Y & Y & Y & C & Y & Y & Y & Y & $9 / 10$ \\
\hline Sullivan-Bolyai et al (2003) & Y & Y & Y & Y & Y & Y & Y & Y & Y & Y & $10 / 10$ \\
\hline Pimentel et al (2017) ${ }^{3}$ & Y & Y & Y & Y & Y & C & Y & Y & C & Y & $8 / 10$ \\
\hline Haslund-Thomsen et al (2020)20 & Y & Y & Y & Y & Y & Y & Y & Y & Y & Y & $10 / 10$ \\
\hline Povlsen et al (2009) ${ }^{21}$ & Y & Y & C & Y & Y & C & Y & Y & Y & Y & $8 / 10$ \\
\hline Martins et al (2014) $)^{22}$ & Y & Y & Y & C & Y & C & Y & C & C & C & $5 / 10$ \\
\hline Kratzer $(2012)^{23}$ & Y & Y & C & Y & Y & C & Y & C & Y & Y & $7 / 10$ \\
\hline Seppänen et al (1999)24 & Y & Y & Y & C & Y & C & C & Y & Y & C & $7 / 10$ \\
\hline Lawton et al (2015) & Y & Y & Y & Y & Y & C & C & Y & Y & Y & $8 / 10$ \\
\hline Wennick et al (2007)26 & Y & Y & Y & Y & Y & Y & Y & Y & Y & Y & $10 / 10$ \\
\hline Wennick et al (2006) ${ }^{27}$ & Y & Y & Y & Y & Y & Y & Y & Y & Y & Y & $10 / 10$ \\
\hline Barone et al (2019) ${ }^{28}$ & Y & Y & Y & C & $C$ & C & Y & Y & C & C & $5 / 10$ \\
\hline Lowes et al (2014) ${ }^{29}$ & Y & Y & C & Y & C & C & C & Y & Y & C & $5 / 10$ \\
\hline Sand et al (2017) & Y & Y & Y & Y & Y & C & Y & Y & Y & Y & $9 / 10$ \\
\hline Nurmi et al $(2012)^{31}$ & Y & Y & Y & C & C & C & C & Y & Y & Y & $6 / 10$ \\
\hline Symons et al (2015) & Y & Y & Y & C & Y & C & C & C & Y & Y & $6 / 10$ \\
\hline Pierce et al (2017) & Y & Y & Y & Y & Y & C & Y & Y & Y & Y & $9 / 10$ \\
\hline Smaldone et al (2011) & Y & Y & C & Y & Y & C & Y & Y & Y & Y & $8 / 10$ \\
\hline Rifshana et al $(2017)^{33}$ & Y & Y & Y & Y & Y & Y & Y & Y & Y & Y & $10 / 10$ \\
\hline Sullivan-Bolyai et al (2006) 34 & Y & Y & Y & C & Y & C & Y & Y & Y & Y & $8 / 10$ \\
\hline Lowes et al (2005) $)^{35}$ & Y & Y & C & Y & Y & Y & Y & Y & Y & Y & $9 / 10$ \\
\hline Spencer et al (2012) ${ }^{36}$ & Y & Y & Y & Y & Y & Y & Y & Y & Y & Y & $10 / 10$ \\
\hline Hatton et al (1995) & Y & Y & Y & Y & Y & C & C & C & Y & Y & $7 / 10$ \\
\hline Khandan et al (2018)38 & Y & Y & Y & Y & Y & Y & Y & Y & Y & Y & $10 / 10$ \\
\hline Lowes et al $(2004)^{39}$ & Y & Y & Y & Y & Y & Y & Y & Y & Y & Y & $10 / 10$ \\
\hline Marshall et al (2009)40 & Y & Y & Y & Y & Y & C & Y & Y & Y & Y & $9 / 10$ \\
\hline Sparud-Lundin et al (2013) & Y & Y & Y & Y & Y & C & Y & Y & Y & Y & $8 / 10$ \\
\hline Smith et al $(2010)^{42}$ & Y & Y & C & C & C & C & C & C & Y & Y & $4 / 10$ \\
\hline Wennick et al (2009)43 & Y & Y & C & Y & Y & C & Y & Y & Y & Y & $8 / 10$ \\
\hline 'Y' total for each question & $32 / 32$ & $32 / 32$ & $26 / 32$ & $25 / 32$ & $28 / 32$ & $10 / 32$ & $26 / 32$ & $27 / 32$ & $29 / 32$ & $28 / 32$ & \\
\hline
\end{tabular}


Table 4 Themes present in included studies

\begin{tabular}{|c|c|c|c|c|c|}
\hline First author and year & $\begin{array}{l}\text { Distressing } \\
\text { diagnostic experience }\end{array}$ & $\begin{array}{l}\text { Change of } \\
\text { life routine }\end{array}$ & $\begin{array}{l}\text { Reconstruction of } \\
\text { family dynamics }\end{array}$ & $\begin{array}{l}\text { Psychological } \\
\text { impact over time }\end{array}$ & $\begin{array}{l}\text { Enablers and barriers } \\
\text { to support from others }\end{array}$ \\
\hline Khandan et al (2018) $)^{17}$ & $x$ & $x$ & $x$ & $x$ & $x$ \\
\hline Albolhassani et al (2013) & $x$ & $x$ & & $x$ & $x$ \\
\hline Anderson et al (2018) ${ }^{2}$ & $x$ & $x$ & $x$ & & $x$ \\
\hline Commissariat et al (2020)19 & & $x$ & $x$ & $x$ & $x$ \\
\hline Sullivan-Bolyai et al (2003) & & $x$ & & $x$ & $x$ \\
\hline Pimentel et al (2017) & $x$ & $x$ & $x$ & $x$ & $x$ \\
\hline Haslund-Thomsen et al $(2020)^{20}$ & $x$ & $x$ & $x$ & $x$ & \\
\hline Povlsen et al (2009) ${ }^{21}$ & $x$ & $x$ & & $x$ & $x$ \\
\hline Martins et al (2013)22 & $x$ & $x$ & $x$ & $x$ & $x$ \\
\hline Kratzer $(2012)^{23}$ & $x$ & $x$ & & $x$ & $x$ \\
\hline Seppänen et al (1999) ${ }^{24}$ & $x$ & $x$ & & $x$ & $x$ \\
\hline Lawton et al $(2014)^{25}$ & & $x$ & $x$ & $x$ & $x$ \\
\hline Wennick et al $(2007)^{26}$ & & $x$ & $x$ & $x$ & $x$ \\
\hline Wennick et al (2006) ${ }^{27}$ & $x$ & & & $x$ & $x$ \\
\hline Barone et al (2019) ${ }^{28}$ & & & $x$ & $x$ & \\
\hline Lowes et al $(2015)^{29}$ & & $x$ & & $x$ & $x$ \\
\hline Sand et al $(2017)^{30}$ & $x$ & & $x$ & $x$ & $x$ \\
\hline Nurmi et al $(2012)^{31}$ & & $x$ & $x$ & & $x$ \\
\hline Crawford et al (2015) & & $x$ & $x$ & $x$ & $x$ \\
\hline Pierce et al (2017) & $x$ & & & $x$ & $x$ \\
\hline Smaldone et al (2011) & $x$ & $x$ & $x$ & $x$ & $x$ \\
\hline Rifshana et al (2017) $)^{33}$ & & $x$ & $x$ & & \\
\hline Sullivan-Bolyai et al (2006) & $x$ & $x$ & $x$ & $x$ & $x$ \\
\hline Lowes et al $(2005)^{35}$ & $x$ & $x$ & $x$ & $x$ & \\
\hline Spencer et al (2012) & $x$ & $x$ & $x$ & $x$ & $x$ \\
\hline Hatton et al (1995) ${ }^{37}$ & $x$ & $x$ & & $x$ & $x$ \\
\hline Khandan et al (2018)38 & $x$ & $x$ & $x$ & $x$ & $x$ \\
\hline Lowes et al $(2004)^{39}$ & $x$ & $x$ & $x$ & $x$ & $x$ \\
\hline Marshall et al (2009)40 & $x$ & $x$ & $x$ & $x$ & \\
\hline Sparud-Lundin et al (2013) & & $x$ & $x$ & $x$ & \\
\hline Smith et al $(2010)^{42}$ & & $x$ & & & \\
\hline Wennick et al (2009)43 & & & & $x$ & $x$ \\
\hline
\end{tabular}




\section{Reconstruction of family dynamics}

This theme was present in 21 of the 32 primary studies which represents $66 \%$ of the studies (Table 4). Family life was experienced as being disrupted for everyone involved as they all had to adapt to a new routine. Some parents reported a positive impact on the parental relationship and family structure, such as better communication with their partner, better family cohesion and healthier lifestyles. Other parents reported negative impacts, such as deterioration in emotional and physical intimacy and spending time together due to sharing care equally. Parents described T1D as being the main topic discussed, and for some this was seen as a positive part of the relationship; however, other parents felt their whole life was now taken up with T1D-related tasks. Parents described their parental role changing to more of a supervisory and controlling role. In parental relationships where there were unequal divisions of T1D care or lack of spousal support, this often led to resentment, tension or, in some cases, ending of their relationship. Parents reported conflict between siblings as a result of the child with T1D getting more attention from the parents although, in some families, siblings were described as being caring towards their sibling with T1D. As a result of raising a child with T1D, parents expressed concerns about having future children in case they too received a diagnosis of T1D.

\section{Navigating appropriate T1D support}

This analytical theme illustrates that the emotional impact of raising a child with T1D persists past diagnosis due to the demands of T1D management and ongoing concerns about their child. The systems surrounding parents played a key role in how supported they felt whilst raising a child with T1D. Parents had difficulties finding and trusting caregivers to provide appropriate support to their child. They had concerns about nursery and school management of T1D and spent time advocating for their child to ensure they received appropriate care. T1D care teams were identified as a key source of support, although parents had mixed experiences of their encounters with them. Parents experienced a lack of understanding from others of the reality of living with T1D, both from their social support network and professionals. Parents longed for more emotional support to be offered by professionals. This analytical theme is explored further below through the descriptive themes from which it was derived: 'psychological impact over time' and 'enablers and barriers to support from others'.

\section{Psychological impact over time}

This theme was present in 28 of the 32 primary studies which represents $88 \%$ of the studies (Table 4). Parents reported feeling overwhelmed, stressed, depressed, guilty, irritable and exhausted from the demands of T1D management. Parents reported a fear of hypoglycemia, which intensified at night-time. Parents struggled with sleep deprivation, which was often linked to night-time fears of finding their child unconscious or dead, leading to them getting up at night to check on their child. In the most severe cases, some parents had considered ending their life in the early weeks following diagnosis while others had been hospitalised. Parents experienced numerous concerns about their T1D child's future including: the child's current and future independent T1D management, long-term health complications including death, and the psychological impact on their child. When parents experienced a crisis or traumatic event such as severe hypoglycemia, their confidence fell and their anxiety increased. Some parents had fears and difficulty with giving injections. Parents had worries about how care providers such as nursery or school would manage their child's T1D care. There were some parents who tried to remain positive by looking at positive aspects of the situation and hoping for a cure for T1D. Some parents also reported feeling like they were coping most of the time.

\section{Enablers and barriers to support from others}

This theme was present in 25 of the 32 primary studies which represents $78 \%$ of the studies (Table 4). Parents felt there was a lack of understanding from others about how T1D is caused or managed - for example, parents felt that others did not understand the constant nature of T1D care. Parents reported difficulty finding caregivers who were able to engage with T1D management; this was partly due to some caregivers not feeling comfortable giving insulin injections. Parents also had difficulty trusting others with providing appropriate care to their child, as they wondered whether they would be able to attend to T1D emergencies - for example, being able to identify and treat hypoglycemia. However, for some parents they did not have a choice but to trust other caregivers due to work commitments. Some parents received support from family and described them as playing an important role in caring for their child, but for other parents there was a lack of support from family who were reluctant to get involved in care. Parents reported a negative impact on their social life as a result of T1D care and management. Parents were concerned by the lack of support from school in adhering to T1D management - for example, not attending to the child's dietary needs or inappropriate care by putting unnecessary restrictions on the child (ie, refusal of snacks or calling an ambulance rather than giving an injection). Parents also experienced school staff as generally lacking sufficient knowledge about T1D which caused concern. However, there were some parents who reported receiving good support from school - for example, some schools had extra staff to support their child with T1D care and provided regular communication with parents.

The T1D healthcare team was viewed as a helpful, valuable resource whose availability and support after discharge was important. Although some parents felt they received a lack of professional support and that the T1D team lacked up-to-date information in developments, giving conflicting advice from within the team. Parents felt that T1D clinic staff did not understand the reality of living with and managing T1D, and had unrealistic expectations of what can be achieved. This resulted in some parents feeling anxious going into clinic appointments as they felt they were going to be reprimanded or judged despite their best efforts. Some parents described positive experiences of the clinic as they felt reassured that they were doing a good job and received good support from T1D professionals. There were some parents who felt there was a lack of emotional support offered and wanted better access to mental health services. Parents advocated for their children to protect them from being mistreated when others may 
not understand or accommodate their needs. Parents viewed participating in T1D fundraising events and interacting with other families living with T1D as helpful and important, and also reduced feelings of isolation, gave a sense of belonging and instilled hope.

\section{Discussion}

In this review, 32 studies on parents' experiences of raising a child with T1D from 13 countries were thematically synthesised. The findings revealed that, when a child is diagnosed with T1D, the parents enter a new reality of living with T1D to which they have to adapt. Highly prevalent from the studies was the psychological impact over time, with parents reporting feeling overwhelmed, stressed and depressed, which was likely as a result of the change of life routine.

These findings support the systematic review by Whittemore et al, ${ }^{6}$ with parents describing diagnosis as an emotionally distressing experience, family life being disrupted by T1D and the psychological impact of raising a child with T1D. Similarly, a review that examined parenting stress among caregivers of children with chronic illness ${ }^{10}$ found parents experienced significantly greater general parenting stress than caregivers of healthy children, and this stress is also associated with poorer psychological adjustment. This would suggest that this current review sheds further light on the fact that, despite the recommendations made in these reviews and probable subsequent developments in clinical practice or management of T1D, parents still experience difficulties in these areas.

This qualitative synthesis provides an important original contribution to knowledge by highlighting the specific difficulties some parents experience in receiving appropriate support from school and in T1D clinic appointments, with some parents feeling that clinic staff do not understand the reality of living with and managing T1D, which has the potential to impact on their psychological well-being.

In line with National Institute for Health and Care Excellence (NICE) guidelines for T1D management, ${ }^{11}$ school staff supporting children with T1D should have regular liaison with diabetes teams with adequate information provision and parents should be offered signposting to diabetes support groups and organisations. There also needs to be regular screening for parental mental health difficulties, which has been recommended to occur from the point of diagnosis, ${ }^{12}$ especially for suicidal thoughts in the immediate postdiagnosis period. If a need is indicated, parents should be provided with access or appropriate referrals to mental health professionals. ${ }^{11,13}$ Psychological interventions and parenting interventions can help to reduce parental ditstress. ${ }^{14,15}$

Healthcare professionals should be aware of the impact of raising a child with T1D on the parents' relationship; they should enquire and assess for family conflict, negotiating a plan for resolution or referring to appropriate mental health support where appropriate. ${ }^{13}$ NICE recommends that parents who are experiencing diabetes-related family conflict should be offered specific family-based behavioural interventions, such as behavioural family systems therapy. ${ }^{11}$ This aligns with existing research that has found behavioural family systems therapy, focused on communication styles, results in reduced diabetes-specific conflict. ${ }^{16}$ Intervening early could have positive outcomes and potentially keep families together, therefore maintaining support for the whole family.

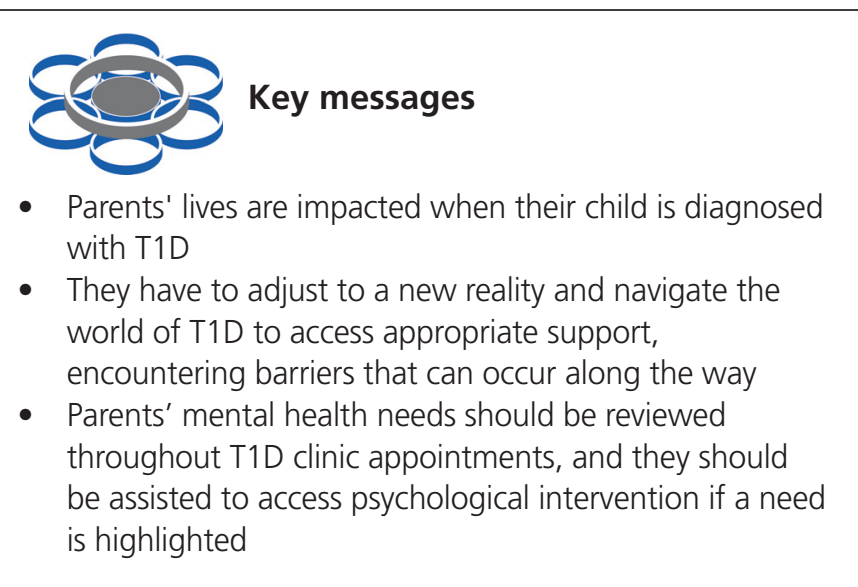

Healthcare professionals should be aware of the anxiety parents may feel about clinic appointments and the impact this can have on their mental health if they feel they are not able to live up to staff expectations. Healthcare professionals should ensure they are realistic with their expectations, empathic, praise and acknowledge parents' effort when they are trying their best, whilst avoiding judgement to help reduce any feelings of anxiety and blame. Additionally, where possible they should ensure that conflicting advice isn't given to parents from different clinic staff.

The strengths of this review include the extensive amount of data over 25 years across multiple countries and the comprehensive analytical approach to searches and data analysis, as well as including a critical appraisal of all studies and attempting to contact authors where information was unclear. Additionally, it was prospectively registered on Prospero to reduce the potential for bias and enhance transparency in outcome reporting. A limitation of this review is that language restrictions were in place which meant that relevant data may have been missed. Moreover, there was limited diversity in the sample of participants in relation to reported ethnicity and gender, which has the ability to impact on parental experiences. There was a notable difference in mother and father participants, with the perspectives of fathers being infrequent. Other areas which can influence the parental experience include characteristics such as employment status, education, relationship status and underlying mental health issues/anxieties. Future research should investigate these areas and have a broader diverse participant pool that is reflective of the population, which should include more fathers and participants from more culturally diverse backgrounds to ascertain their experience and enhance their voice within the literature.

Author contributorship CJ assisted with cross-referencing and rating of study quality. All authors assisted in interpretation of themes, revised the manuscript and approved the final version.

\section{Conflict of interest None. Funding None.}

\section{References}

1. Pierce J, Aroian K, Caldwell C, et al. The ups and downs of parenting young children with type 1 diabetes: a crowdsourcing study. J Pediatr Psychol 2017;42(8):846-60. http://dx. doi.org/10.1093/jpepsy/jsx056

2. Anderson M, Tulloch-Reid M. "How am I gonna cope?": Caregivers of adolescents with diabetes in Jamaica. Chronic Illness 2018;15(4):293-305. http://dx.doi.org/10.1177/1742395318769373 
3. Pimentel RRS, Targa T, Scardoelli MGC. From diagnosis to the unknown: perceptions of parents of children and adolescents with diabetes mellitus. J Nursing UFPE 2017;11(3):1118-26.

4. Symons J, Crawford R, Isaac D, Thompson S. "The whole day revolves around it": families' experiences of living with a child with type 1 diabetes - a descriptive study. Neonatal Paediatr Child Health Nurs 2015;18(1):711.

5. Sullivan-Bolyai S, Deatrick J, Gruppuso P, Tamborlane W, Grey M. Constant vigilance: mothers' work parenting young children with type 1 diabetes. J Pediatr Nurs 2003;18(1):21-9. https://dx.doi.org/10.1053/ jpdn.2003.4

6. Whittemore R, Jaser S, Chao A, Jang M, Grey M. Psychological experience of parents of children with type 1 diabetes. Diabetes Educ 2012;38(4):56279. $\mathrm{http}: / / \mathrm{dx}$.doi.org/10.1177/0145721712445216

7. Moher D, Liberati A, Tetzlaff J, Altman D. Preferred reporting items for systematic reviews and meta-analyses: the PRISMA statement. PLoS Med 2009;6(6):2535. https://dx.doi.org/10.1136/bmj.b2535

8. Critical Appraisal Skills Programme UK. CASP checklists [Internet]. 2020. Available from: https://casp-uk.net/wp-content/uploads/2018/01/CASPQualitative-Checklist-2018.pdf (accessed 8 Nov 2020).

9. Thomas J, Harden A. Methods for the thematic synthesis of qualitative research in systematic reviews. BMC Med Res Methodol 2008;8(1). https://dx.doi.org/10.1186/1471-2288-8-45

10. Cousin KM, Hazen AR. Parenting stress among caregivers of children with chronic illness: a systematic review. J Pediatr Psychol 2013;38(8):809-28. https://dx.doi.org/10.1093/jpepsy/jst049

11. National Institute for Health and Care Excellence. Diabetes (type 1 and type 2 ) in children and young people: diagnosis and management. NICE guideline [NG18]. London: NICE, 2015 (updated Aug 2016). Available from: https://www.nice.org.uk/guidance/ng18/chapter/Patientcentred-care (accessed 8 Nov 2020).

12. Cameron FJ, Northam EA, Ambler GR, Daneman D. Routine psychological screening in youth with type 1 diabetes and their parents: a notion whose time has come? Diabetes Care 2007;30(10):2716-24. https://dx.doi.org/ $10.2337 / \mathrm{dc0}-0603$

13. American Diabetes Association. 13. Children and Adolescents: Standards of Medical Care in Diabetes-2020. Diabetes Care 2020;43(1):S163-S182. http://dx.doi.org/10.2337/dc20-S013

14. Hoff AL, Mullins LL, Gillaspy SR, Page MC, Van Pelt JC, Chaney JM. An intervention to decrease uncertainty and distress among parents of children newly diagnosed with diabetes: a pilot study. Families Systems Health 2005;23(3):329-42. https://dx.doi.org/10.1037/1091-7527.23.3.329

15. Lohan A, Morawska A, Mitchell A. A systematic review of parenting interventions for parents of children with type 1 diabetes. Child Care Health Dev 2015;41(6):803-17. http://dx.doi.org/10.1111/cch.12278

16. Wysocki T, Harris MA, Greco P, et al. Randomized, controlled trial of behavior therapy for families of adolescents with insulin-dependent diabetes mellitus. J Pediatr Psychol 2000;25(1):23-33. http://dx.doi.org/10.1093/ jpepsy/25.1.23

17. Khandan M, Tirgari B, Abazari F, Cheraghi M A. Mothers' experiences of maze path of type 1 diabetes diagnosis in children. Ethiop J Health Sci 2018;28(5):635-44.

18. Abolhassani S, Babaee $S$, Eghbali M. Mothers' experience of having children with diabetes. Iran J Nurs Midwifery Res 2013;18(4):304-9.

19. Commissariat $P$, Harrington $K$, Whitehouse $A$, et al. "I'm essentially his pancreas": Parent perceptions of diabetes burden and opportunities to reduce burden in the care of children <8years old with type 1 diabetes. Pediatr Diabetes 2019;21(2):377-83. https://dx.doi.org/10.1111/pedi.12956

20. Haslund-Thomsen $\mathrm{H}$, Hasselbalch LA, Laugesen B. Parental experiences of continuous glucose monitoring in Danish children with type 1 diabetes mellitus. J Pediatr Nurs 2020;53:E149-E155. https://dx.doi.org/10.1016/ j.pedn.2020.03.010

21. Povlsen L, Ringsberg KC. Learning to live with a child with diabetes--problems related to immigration and cross-cultural diabetes care. Scand J Caring Sci 2009;23(3):482-9. https://dx.doi.org/10.1111/j.1471-6712. 2008.00644.x

22. Martins EMCS, de Ataíde MBC, Silva DMA, Frota MA. Experience of mothers in the care of children with type 1 diabetes. Rev Rene 2013;14(1):42-9.

23. Kratzer J. Structural barriers to coping with type 1 diabetes mellitus in Ghana: experiences of diabetic youth and their families. Ghana Med J 2012;46(2):39-45.
24. Seppänen SM, Kyngäs HA, Nikkonen MJ. Coping and social support of parents with a diabetic child. Nurs Health Sci 1999;1(1):63-70. http://dx.doi.org/10.1046/j.1442-2018.1999.00009.x

25. Lawton J, Waugh N, Barnard KD, et al. Challenges of optimizing glycaemic control in children with type 1 diabetes: a qualitative study of parents' experiences and views. Diabet Med 2015;32(8):1063-70. https://dx.doi.org/ 10.1111/dme. 12660

26. Wennick A, Hallstrom I. Families' lived experience one year after a child was diagnosed with type 1 diabetes. J Adv Nurs 2007;60(3):299-307. https://dx.doi.org/10.1111/j.1365-2648.2007.04411.x

27. Wennick A, Hallstrom I. Swedish families' lived experience when a child is first diagnosed as having insulin-dependent diabetes mellitus - an ongoing learning process. J Fam Nurs 2006;12(4):368-89. https://dx.doi.org/ 10.1177/1074840706296724

28. Barone M, Savarese L, Freda MF. Living with a chronic disease: the role of maternal mediation in the meaning-making process of their children's type 1 diabetes. Med J Clin Psychol 2019;7(3). https://dx. doi.org/ 10.6092/22821619/2019.7.2187

29. Lowes L, Eddy D, Channon S, et al. The experience of living with type 1 diabetes and attending clinic from the perception of children, adolescents and carers: analysis of qualitative data from the DEPICTED study. J Pediatr Nurs 2015;30(1):54-62. https://dx.doi.org/10.1016/j.pedn.2014.09.006

30. Sand P, Blom MD, Forsander G, Lundin CS. Family dynamics when a child becomes chronically ill: impact of type 1 diabetes onset in children and adolescents. Nord Psychol 2018;70(2):97-114. https://dx.doi.org/ 10.1080/19012276.2017.1362990

31. Nurmi MA, Stieber-Roger K. Parenting children living with type 1 diabetes: a qualitative study. Diabetes Educ 2012;38(4):530-6. https://dx.doi.org/ 10.1177/0145721712446636

32. Smaldone A, Ritholz MD. Perceptions of parenting children with type 1 diabetes diagnosed in early childhood. J Pediatr Health Care 2011;25(2):8795. https://dx.doi.org/10.1016/j.pedhc.2009.09.003

33. Rifshana F, Breheny M, Taylor JE, Ross K. The parental experience of caring for a child with type 1 diabetes. J Child Fam Stud 2017;26(11):3226-36. https://dx.doi.org/10.1007/s10826-017-0806-5

34. Sullivan-Bolyai S, Rosenberg R, Bayard M. Fathers' reflections on parenting young children with type 1 diabetes. MCN Am J Matern Child Nurs 2006;31(1):24-31. https://dx.doi.org/10.1097/00005721-20060100000007

35. Lowes L, Gregory JW, Lyne P. Newly diagnosed childhood diabetes: a psychosocial transition for parents? J Adv Nurs 2005;50(3):253-61. https://dx.doi.org/10.1111/j.1365-2648.2005.03388.x

36. Spencer JE, Cooper HC, Milton B. The lived experiences of young people (13-16 years) with type 1 diabetes mellitus and their parents--a qualitative phenomenological study. Diabet Med 2014;30(1):17-24. https://dx.doi.org/ 10.1111/dme. 12021

37. Hatton DL, Canam C, Thome S, Hughes AM. Parents' perceptions of caring for an infant or toddler with diabetes. J Adv Nurs 1995;22(3): 569-77. https://dx.doi.org/10.1046/j.1365-2648.1995.22030569.x

38. Khandan $M$, Abazari F, Tirgari B, et al. Lived experiences of mothers with diabetic children from the transfer of caring role. Int I Community Based Nurs Midwifery 2018;6(1):76-88

39. Lowes L, Lyne P, Gregory JW. Childhood diabetes: parents' experience of home management and the first year following diagnosis. Diabet Med 2004;21(6):531-8. http://dx. doi.org/10.1111/j.1464-5491.2004.01193.x

40. Marshall M, Carter B, Rose K, Brotherton A. Living with type 1 diabetes: perceptions of children and their parents. J Clin Nurs 2009;18(12):170310. https://dx.doi.org/10.1111/j.1365-2702.2008.02737.x

41. Sparud-Lundin C, Hallström I, Erlandsson LK. Challenges, strategies, and gender relations among parents of children recently diagnosed with type 1 diabetes. J Fam Nurs 2013;19(2): 249-73. https://dx.doi.org/10.1177/ 1074840713484386

42. Smith J, Nabors L, Henderson E, Kichler J, Andreone LT. Parent and child perceptions of managing childhood diabetes. In: Fortier C, Turcotte $S$, eds. Health Education: Challenges, Issues and Impact. Nova Science Publishers, 2010, 229-36.

43. Wennick A, Lundqvist A, Hallström I. Everyday experience of families three years after diagnosis of type 1 diabetes in children: a research paper. J Pediatr Nurs 2009;24(3):222-30. https://dx.doi.org/10.1016/ j.pedn.2008.02.028 
Appendix 1. PRISMA 2009 Checklist

\begin{tabular}{|c|c|c|c|}
\hline Section/topic & \# & Checklist item & $\begin{array}{l}\text { Reported } \\
\text { on page \# }\end{array}$ \\
\hline \multicolumn{4}{|l|}{ TITLE } \\
\hline Title & 1 & Identify the report as a systematic review, meta-analysis, or both. & 1 \\
\hline \multicolumn{4}{|l|}{ ABSTRACT } \\
\hline Structured summary & 2 & $\begin{array}{l}\text { Provide a structured summary including, as applicable: background; objectives; data sources; study eligibility criteria, } \\
\text { participants, and interventions; study appraisal and synthesis methods; results; limitations; conclusions and } \\
\text { implications of key findings; systematic review registration number. }\end{array}$ & 2 \\
\hline \multicolumn{4}{|l|}{ INTRODUCTION } \\
\hline Rationale & 3 & Describe the rationale for the review in the context of what is already known. & 3 \\
\hline Objectives & 4 & $\begin{array}{l}\text { Provide an explicit statement of questions being addressed with reference to participants, interventions, comparisons, } \\
\text { outcomes, and study design (PICOS). }\end{array}$ & 3 \\
\hline \multicolumn{4}{|l|}{ METHODS } \\
\hline Protocol and registration & 5 & $\begin{array}{l}\text { Indicate if a review protocol exists, if and where it can be accessed (e.g., Web address), and, if available, provide } \\
\text { registration information including registration number. }\end{array}$ & 3 \\
\hline Eligibility criteria & 6 & $\begin{array}{l}\text { Specify study characteristics (e.g., PICOS, length of follow-up) and report characteristics (e.g., years considered, } \\
\text { language, publication status) used as criteria for eligibility, giving rationale. }\end{array}$ & 3 \\
\hline Information sources & 7 & $\begin{array}{l}\text { Describe all information sources (e.g., databases with dates of coverage, contact with study authors to identify } \\
\text { additional studies) in the search and date last searched. }\end{array}$ & 3 \\
\hline Search & 8 & $\begin{array}{l}\text { Present full electronic search strategy for at least one database, including any limits used, such that it could be } \\
\text { repeated. }\end{array}$ & 3 \\
\hline Study selection & 9 & $\begin{array}{l}\text { State the process for selecting studies (i.e., screening, eligibility, included in systematic review, and, if applicable, } \\
\text { included in the meta-analysis). }\end{array}$ & $3-4$ \\
\hline Data collection process & 10 & $\begin{array}{l}\text { Describe method of data extraction from reports (e.g., piloted forms, independently, in duplicate) and any processes } \\
\text { for obtaining and confirming data from investigators. }\end{array}$ & $3-4$ \\
\hline Data items & 11 & $\begin{array}{l}\text { List and define all variables for which data were sought (e.g., PICOS, funding sources) and any assumptions and } \\
\text { simplifications made. }\end{array}$ & NA \\
\hline $\begin{array}{l}\text { Risk of bias in individual } \\
\text { studies }\end{array}$ & 12 & $\begin{array}{l}\text { Describe methods used for assessing risk of bias of individual studies (including specification of whether this was } \\
\text { done at the study or outcome level), and how this information is to be used in any data synthesis. }\end{array}$ & 4 \\
\hline Summary measures & 13 & State the principal summary measures (e.g., risk ratio, difference in means). & NA \\
\hline Synthesis of results & 14 & $\begin{array}{l}\text { Describe the methods of handling data and combining results of studies, if done, including measures of consistency } \\
\left(\text { e.g., } I^{2} \text { ) for each meta-analysis. }\right.\end{array}$ & 4 \\
\hline Risk of bias across studies & 15 & $\begin{array}{l}\text { Specify any assessment of risk of bias that may affect the cumulative evidence (e.g., publication bias, selective } \\
\text { reporting within studies). }\end{array}$ & NA \\
\hline Additional analyses & 16 & $\begin{array}{l}\text { Describe methods of additional analyses (e.g., sensitivity or subgroup analyses, meta-regression), if done, indicating } \\
\text { which were pre-specified. }\end{array}$ & NA \\
\hline \multicolumn{4}{|l|}{ RESULTS } \\
\hline Study selection & 17 & $\begin{array}{l}\text { Give numbers of studies screened, assessed for eligibility, and included in the review, with reasons for exclusions at } \\
\text { each stage, ideally with a flow diagram. }\end{array}$ & Figure 1 \\
\hline Study characteristics & 18 & $\begin{array}{l}\text { For each study, present characteristics for which data were extracted (e.g., study size, PICOS, follow-up period) and } \\
\text { provide the citations. }\end{array}$ & $\begin{array}{l}4 \text { and } \\
\text { Table } 2\end{array}$ \\
\hline Risk of bias within studies & 19 & Present data on risk of bias of each study and, if available, any outcome level assessment (see item 12). & $\begin{array}{l}\text { 4-5 and } \\
\text { Table } 3\end{array}$ \\
\hline Results of individual studies & 20 & $\begin{array}{l}\text { For all outcomes considered (benefits or harms), present, for each study: (a) simple summary data for each } \\
\text { intervention group (b) effect estimates and confidence intervals, ideally with a forest plot. }\end{array}$ & Table 2 \\
\hline Synthesis of results & 21 & Present results of each meta-analysis done, including confidence intervals and measures of consistency. & $5-9$ \\
\hline Risk of bias across studies & 22 & Present results of any assessment of risk of bias across studies (see Item 15). & NA \\
\hline Additional analysis & 23 & Give results of additional analyses, if done (e.g., sensitivity or subgroup analyses, meta-regression [see Item 16]). & NA \\
\hline \multicolumn{4}{|l|}{ DISCUSSION } \\
\hline Summary of evidence & 24 & $\begin{array}{l}\text { Summarize the main findings including the strength of evidence for each main outcome; consider their relevance to } \\
\text { key groups (e.g., healthcare providers, users, and policy makers). }\end{array}$ & $9-11$ \\
\hline Limitations & 25 & $\begin{array}{l}\text { Discuss limitations at study and outcome level (e.g., risk of bias), and at review-level (e.g., incomplete retrieval of } \\
\text { identified research, reporting bias). }\end{array}$ & 11 \\
\hline Conclusions & 26 & Provide a general interpretation of the results in the context of other evidence, and implications for future research. & $9-11$ \\
\hline \multicolumn{4}{|l|}{ FUNDING } \\
\hline Funding & 27 & $\begin{array}{l}\text { Describe sources of funding for the systematic review and other support (e.g., supply of data); role of funders for the } \\
\text { systematic review. }\end{array}$ & NA \\
\hline
\end{tabular}

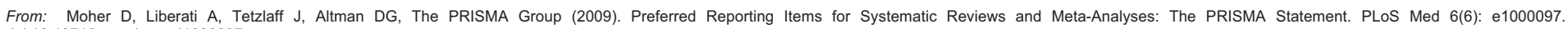
doi:10.1371/journal.pmed1000097 
Appendix 2. Search Strategy

Eleven databases (Ebscohost [CINAHL, Medline, Psycharticles, Psychinfo, Psychology and Behavioural Sciences, Child Adolescent Development Studies], Web of Science, Cochrane Library, PubMed, Scopus and British Nursing Index) were systematically searched from their inception to May 2020. The search terms used were: (1) parents or caregivers or mother or mum or mom or father or dad or parent or guardian, (2) diabetes, (3) Challenge* or attit* or experience* or view* or perce* or cop* or behav* or diffic* or belief* or rais*. 